NBER WORKING PAPER SERIES

DOES DRINKING REALLY DECREASE IN BAD TIMES?

\author{
Christopher J. Ruhm \\ William E. Black \\ Working Paper 8511 \\ http://www.nber.org/papers/w8511 \\ NATIONAL BUREAU OF ECONOMIC RESEARCH \\ 1050 Massachusetts Avenue \\ Cambridge, MA 02138 \\ October 2001
}

We thank Michael Grossman, Doug Staiger, and participants of the Triangle Applied Microeconomics Conference and NBER Summer Institute Health Economics workshop for helpful comments and Olga Khavjou for helpful research assistance. Ruhm gratefully acknowledges financial support from the National Institute on Alcohol Abuse and Alcoholism (AA12309) and the National Science Foundation (SES-9876511). The views expressed herein are those of the authors and not necessarily those of the National Bureau of Economic Research.

(C) 2001 by Christopher J. Ruhm and William E. Black. All rights reserved. Short sections of text, not to exceed two paragraphs, may be quoted without explicit permission provided that full credit, including $($ C notice, is given to the source. 
Does Drinking Really Decrease in Bad Times?

Christopher J. Ruhm and William E. Black

NBER Working Paper No. 8511

October 2001

JEL No. E32, I12, I18

\begin{abstract}
$\underline{\text { ABSTRACT }}$
This paper investigates the relationship between macroeconomic conditions, alcohol use, and drinking problems using individual-level data from the 1987-1999 years of the Behavioral Risk Factor Surveillance System. We confirm the procyclical variation in overall drinking identified in previous research using aggregate sales data and show that this largely results from changes in consumption among existing drinkers, rather than movements into or out of drinking. Moreover, the decrease in alcohol use occurring during bad economic times is concentrated among heavy consumers, with light drinking actually increasing in these periods. We find no evidence that the decline in overall drinking masks a rise in alcohol use for persons becoming unemployed during contractions, suggesting that any stress-induced increases in consumption are more than offset by reductions resulting from changes in economic factors such as lower incomes.
\end{abstract}

Christopher J. Ruhm

Department of Economics

444 Bryan School

University of North Carolina at Greensboro

P.O. Box 26165

Greensboro, NC 27402-6165

and NBER

c_ruhm@uncg.edu
William E. Black

Mathematica Policy Research, Inc.

P.O. Box 2393

Princeton, NJ 08543-2393

wblack@mathematica-mpr.com 


\section{Does Drinking Really Decrease in Bad Times?}

Research emphasizing psychological responses to economic downturns suggests that alcohol use will rise during these periods as a form of self-medication for stress, with particularly large growth in abusive drinking and risky behaviors such as drunk driving (e.g. Brenner and Mooney, 1983; Winton, et al, 1986; Pierce, et al., 1994). However, the causal effects of macroeconomic conditions are actually more complicated. A separate psychological literature emphasizes the role of job stress (e.g. Baker, 1985; Karsek and Theorell, 1990; Sokejima and Kagamimori, 1998), implying that drinking may increase with the intensity of employment. ${ }^{1}$ Previous research also indicates that consumption is positively related to incomes (e.g. Skog, 1986; Sloan et al., 1995, Ruhm 1995). Thus, stress-induced drinking during depressed periods might be partially or fully offset by reductions due to decreased earnings. Conversely, the opportunity cost of alcohol use might fall if the negative consequences of intoxication during the work-day are reduced due to declining work hours or increased unemployment. ${ }^{2}$ Finally, the drinking patterns could differ across groups. For instance, employed individuals might drink less while alcohol problems increase among the newly unemployed. ${ }^{3}$

This paper analyzes the relationship between economic conditions and drinking behavior using individual-level data from the Behavioral Risk Factor Surveillance System (BRFSS).

Several features make this study unique. First, we consider a wider range of outcomes than in previous research, including differences in the responsiveness of "light" and "heavy" drinkers. Second, we provide the first examination of the dynamics of the adjustment of alcohol use to changes in macroeconomic conditions. Third, we explore whether the cyclical fluctuations differ across population subgroups stratified by sex, race/ethnicity, age, and employment status.

\footnotetext{
${ }^{1}$ Fenwick and Tausig (1994) discuss the relationship between economic conditions and stress among employed individuals.

${ }^{2}$ However, the costs of drinking may rise for employed persons who fear the loss of jobs.

${ }^{3}$ Catalano et al., (1993) find a lower risk of alcohol-related disorders for workers during times of unexpectedly low levels of employment.
} 
Our investigation confirms the procyclical variation in overall drinking identified in

previous research. In addition we show that almost all of the fluctuation results from changes in consumption for existing drinkers, instead of entry or exit into alcohol use. In fact, decreased drinking during bad times is dominated by reductions in heavy rather than recreational drinking. Although the strength of the macroeconomic fluctuations differs across demographic groups, the patterns of effects appear fairly universal. Finally, we uncover no evidence that drinking increases among persons becoming newly unemployed during bad economic times.

\section{Previous Research}

There has been considerable research examining how alcohol use is affected by taxes or prices, minimum legal drinking ages, restrictions on availability, and laws aimed at reducing drunk-driving. ${ }^{4}$ By contrast, macroeconomic conditions have received less attention. Ruhm (1995) investigates how these are related to alcohol consumption and highway vehicle fatalities using aggregate data for the 48 contiguous states over the $1975-1988$ time period. The primary finding is that drinking and vehicle mortality vary procyclically. ${ }^{5}$ One reason is that incomes grow when the economy expands and alcohol is a normal good. Freeman (1999) raises concern that the data used by Ruhm may be non-stationary. Nevertheless, using an expanded data set (covering the 50 states and District of Columbia for the $1970-1995$ period) that is rendered stationary by using growth rates instead of levels, he confirms the procyclical variation of alcohol consumption. ${ }^{6}$

\footnotetext{
${ }^{4}$ U.S. Department of Health and Human Services (2000) provides a useful recent literature review on price elasticities and alcohol taxation. The effects of availability constraints and minimum drinking ages are discussed in Gruenewald (1993) and Wagenaar (1993). Cook and Moore (2000) provide an excellent overview of economic research related to alcohol.

${ }^{5}$ For example, a one standard deviation (2.12 percentage point) increase in the state unemployment rate is predicted to reduce drinking by 1.3 percent and traffic fatalities by almost 7 percent. The consumption of distilled spirits is more sensitive to macroeconomic conditions than purchases of beer or wine. These results are consistent with the findings of earlier research by O'Neill (1984) and Evans \& Graham (1988) indicating that vehicle fatalities and single vehicle night-time crashes (which frequently involve drunk-driving) are procyclical and those of Wagenaar \& Streff (1989) suggesting that alcohol consumption increases in good times.

${ }^{6}$ Freeman finds that the failure to correct for non-stationarity yields parameter estimates that are sensitive to the choice of time periods. However, this may be an artifact of differences in the alcohol data used. Specifically, Ruhm
} 
The use of aggregate data in these studies introduces several complications. First, the set of covariates controlled for is generally limited. ${ }^{7}$ Second, it is difficult to ascertain individual behavior; this is often referred to as the "ecological inference" problem. For example, overall alcohol consumption might fall during recessions because of decreases among recreational users, even while heavy drinking increases. Since moderate alcohol use has recently been linked to health benefits (e.g. Gaziano, et al., 1993; Thun, et al., 1997) and drinking problems are likely to be concentrated among those imbibing large amounts, reductions in total use could therefore mask increases in alcohol abuse. ${ }^{8}$ Similarly, consumption might decline in bad times because workers drink less, even while persons becoming newly unemployed raise their intake of alcohol. Such a pattern might help to reconcile the psychological literature emphasizing drinking as self-medication for the stress of unemployment with an overall procyclical pattern of alcohol use. $^{9}$ Potential differences across sex, race/ethnicity, or age groups also can not be identified using aggregate sales data. ${ }^{10}$

These shortcomings indicate that much can be gained by investigating the relationship between economic conditions and drinking behavior with microdata. The few previous studies doing so yield inconclusive results. Ettner's (1997) analysis of the 1988 National Health Interview Survey concludes that alcohol consumption and dependence are procyclical.

transforms the consumption of beer, wine, and distilled spirits into ethanol-equivalents using constant conversion rates. By contrast, Freeman's information is from the Alcohol Epidemiologic Data System (AEDS) where the conversion factors vary over time. In the AEDS data, wine is assumed contain 16.0 percent alcohol prior to 1972 , 14.5 percent from 1972 to 1976, and 12.9 percent after 1976; distilled spirits are assumed to contain 45.0, 43.0, and 41.1 percent alcohol in the three periods. Such sharp discontinuities could render Freeman's data non-stationary.

${ }^{7}$ This shortcoming can be partially surmounted by estimating fixed-effect models, which automatically account for time-invariant location-specific factors.

${ }^{8}$ Some empirical evidence supports the possibility of differential responses for light and heavy drinkers. Manning et al. (1995) find that the price elasticity of demand for alcohol is fairly high for recreational drinkers but is approximately zero for the heaviest consumers. Kenkel (1996) indicates lower price elasticities for heavy than moderate drinkers, particularly for those who are poorly informed about the related health risks. On the other hand, Cook \& Tauchen (1982) show that cirrhosis mortality, which disproportionately affects heavy drinkers, is a declining function of alcohol taxes, indicating that even these individuals are price sensitive.

${ }^{9}$ Feather (1990) provides an excellent review of the literature on the relationship between employment, joblessness, and psychological well-being. Theodossiou (1998) supplies an example of recent economic research on this topic. 10 Another possible shortcoming is that aggregate sales data do not accurately account for cross-border purchases, home or illegal production, breakage, or untaxed alcohol brought into the country from abroad. 
However, the results for involuntary unemployment are mixed (it is associated with more drinking but less alcohol dependence), indicating potentially nonuniform impacts of the macroeconomy. Moreover, Ettner's use of cross-sectional data implies that the impact of economic conditions may be confounded with unobserved determinants of drinking that vary across states. $^{11}$

Dee (2001) avoids some of these problems by estimating fixed-effect models using data from the 1984-1995 years of the Behavioral Risk Factor Surveillance System. He obtains the contradictory result that increases in state unemployment rates are associated with reductions in overall drinking and in the probability of consuming 60 or more drinks per month but also with a higher likelihood of consuming five or more drinks on a single occasion. Conversely, Ruhm's (2000) analysis of BRFSS data for the 1987 to 1995 period suggests a countercyclical variation in alcohol consumption. One possible reason for these inconsistent findings is that Dee and Ruhm include both year and state dummy variables in their models, although doing so removes most of the sample variation in unemployment. A second is that neither study weights the data for differences in sampling probabilities, even though the survey is only nationally representative after weighting and (as shown below) there are sharp differences in drinking behavior across demographic groups. Finally, only a limited set of explanatory variables are included. For instance, neither Dee nor Ruhm control for alcohol taxes or prices.

We improve on prior research in several ways. First, our analysis of the BRFSS data covers a longer (and more recent) period. Second, we consider a broader array of outcomes, paying particular attention to the distinction between recreational drinking and heavy alcohol use. Third, we investigate the dynamics of the adjustment to sustained changes in

\footnotetext{
${ }^{11}$ Ettner sometimes uses state unemployment rates to instrument individual labor market status. However, this IV approach is only valid if the former influence drinking exclusively through their impact on employment. Evidence presented below casts doubt on this.
} 
macroeconomic conditions. Fourth, we offer a more complete examination of differences in drinking behavior on the basis of age, sex, race/ethnicity, and employment status. ${ }^{12}$

\section{Data and Methods of Analysis}

Data are from the 1987-1999 interview years of the Behavioral Risk Factor Surveillance System. The BRFSS, administered by the Centers for Disease Control and Prevention, is an annual telephone survey of the non-institutionalized adult population designed to produce uniform state-specific data on preventive health practices and risky behaviors, including alcohol use and abuse. One goal of the survey is to enable public health professionals to monitor state and national progress towards meeting the Healthy People 2000: National Health Promotion and Disease Prevention Objectives. Only 15 states participated in the BRFSS in its first year (1984) but 34 states did so by 1987 and 45 or more in each year of the 1990s. Sample sizes are large, exceeding fifty thousand in each year that we analyze, and they increase over time so that our 13year sample contains over one million observations. Information on alcohol use is available for all respondents except those interviewed in 1994, 1996, and 1998, when these questions were restricted to optional modules included by 12,17 , and 12 states respectively. ${ }^{13}$

The BRFSS, while extremely useful for this analysis, does contain several limitations. First, since the data are obtained from telephone surveys of residential households, persons without phones or whose abode is non-residential (e.g. military bases, college dorms, or institutions) are excluded. Second, no information is provided on youths (under the age of 18). Third, alcohol use is likely to be understated in self-reported data. ${ }^{14}$ However, this will only bias the estimates if the underreporting systematically differs with economic conditions. Fourth, the

\footnotetext{
12 Dee (2001) provides a limited investigation of demographic group differences in binge drinking.

${ }^{13}$ There were 22,046, 43,424, and 32,472 respondents to the alcohol modules in the three years. Further information on the BRFSS can be obtained from the web-site: http://www.cdc.gov/nccdphp/brfss.

${ }^{14}$ Midnak (1982) indicates that the drinking reported in general population surveys may account for only 40 to 60 percent of total alcohol sales, suggesting substantial underreporting. However, the self-report errors appear to be consistent over time (Johnston et al., 1992), implying that estimates of time trends are unbiased.
} 
responses must be weighted to make the BRFSS fully representative of the target adult population.

\section{$\underline{2.1}$ Dependent Variables}

The BRFSS collects various information on alcohol use. Respondents are asked whether they had at least one drink of any alcoholic beverage during the prior month. Those answering in the affirmative are questioned about the number of drinks, whether they had more than five drinks on a single occasion, and if they had driven after having "had perhaps too much to drink." 15 Using these data, we created several dependent variables, all referring to alcohol use in the last month. "Drinking participation" has a value of one (zero) for persons with some (no) consumption. "Conditional drinking" indicates the number of alcoholic beverages imbibed by drinkers. "Alcohol-involved driving" is a dummy variable set to one for persons who have driven when they "had perhaps to much to drink." Dummy variables for conditional drinking in the ranges of $1-10,1-20,21-59, \geq 60$, and $\geq 100$ alcoholic beverages are used to distinguish between "light," "moderate," and "heavy" drinking. Finally, "binge drinking" is a binary outcome indicating whether consumers had imbibed five or more beverages on a single occasion.

The distinction between drinking participation and conditional drinking is common in health applications and is motivated by the assumption that the process distinguishing some versus no use may be distinct from that generating alternative positive values. ${ }^{16}$ In this formulation, expected consumption for individual $\mathrm{i}$ with characteristics $\mathrm{X}$ is determined by:

$$
\mathrm{E}\left[\mathrm{Y}_{\mathrm{i}} \mid \mathrm{X}_{\mathrm{i}}\right]=\operatorname{Pr}\left[\mathrm{Y}_{\mathrm{i}}>0 \mid \mathrm{X}_{\mathrm{i}}\right] \quad \mathrm{x} \quad \mathrm{E}\left[\mathrm{Y}_{\mathrm{i}} \mid \mathrm{Y}_{\mathrm{i}}>0, \mathrm{X}_{\mathrm{i}}\right]
$$

where $\mathrm{Y}$ is the number of drinks in the month, $\mathrm{E}($.$) and \operatorname{Pr}($.$) indicate conditional expectations$ and probabilities, and the first (second) term on the right-hand-side of (1) refers to drinking

\footnotetext{
${ }^{15}$ A drink is one can or bottle of beer or wine coolers, one glass of wine, one cocktail, or one shot of liquor.

${ }^{16}$ For this reason, the tobit model may be inappropriate. Mullahy (1998) provides a detailed discussion and critique of the use of two-part models in health economics.
} 
participation (conditional drinking). As is conventional, we assume that the natural log of conditional drinking is linearly related to the explanatory variables according to:

$$
\mathrm{E}\left[\ln \left(\mathrm{Y}_{\mathrm{i}}\right) \mid \mathrm{Y}_{\mathrm{i}}>0, \mathrm{X}_{\mathrm{i}}\right]=\mathrm{X}_{\mathrm{i}} \hat{\beta}
$$

for $\hat{\beta}$ the vector of regression coefficients. We similarly estimate the conditional probabilities

of light, moderate, heavy, or binge drinking after restricting the sample to alcohol users.

A small number of respondents report extremely high (and presumably erroneous) levels of consumption. To avoid assigning these outliers undue influence, we top-code conditional drinking at 450 drinks per month (15 drinks per day). ${ }^{17}$ Information on drinking participation is not reported for 0.2 percent of the sample (2150 individuals), with additional missing values for the other outcomes. ${ }^{18}$ While there does not appear to be a consistent pattern of nonresponse for conditional drinking, missing values for alcohol-involved driving and binge drinking tend to concentrated among heavy consumers. ${ }^{19}$ However, there is no indication that non-response biases the parameter estimates for the macroeconomic variables of key interest. ${ }^{20}$

\section{$\underline{2.2 \text { Explanatory Variables }}$}

Our main proxy for macroeconomic conditions is the survey month state unemployment rate for the civilian non-institutionalized population (aged 16 and over). Data are from the Bureau of Labor Statistics Local Area Unemployment Statistics (LAUS) Database. ${ }^{21}$ Some models include lagged unemployment rates. Others additionally hold constant average annual

\footnotetext{
${ }^{17}$ The top-coding affects 192 of the 1,035,115 respondents, or less than .02 percent of the sample. The results were not sensitive to our experimentation with other criteria for top-coding.

${ }^{18}$ This includes 21,874 persons for whom there is insufficient information to construct the number of drinks consumed, and 2,791 and 7,778 individuals not reporting on alcohol-involved driving or binge drinking.

19 Conditional drinking is more than twice the sample mean for those with missing values for binge drinking or alcohol-involved driving; non-respondents to the driving question binge drink over twice as often as average.

${ }^{20}$ We tested for this by examining whether the parameter estimates on the economic variables changed substantially when observations with missing values were added to the sample and assigned various possible values (e.g. a zero or one in alternative regression estimates for the dichotomous variables).

${ }^{21}$ The web-site http://stats.bls.gov/lauhome.htm contains information on the LAUS. Some regressions also control for the national unemployment rate using monthly data from the Current Population Survey.
} 
state per capita personal income (in thousands of \$1999), deflated by the all-items consumer price index. $^{22}$

The econometric models also control for a quadratic in years of age and dummy variables for sex, education (high school dropout, some college, college graduate), race/ethnicity (nonHispanic black, other non-Hispanic nonwhite, Hispanic origin), marital status (married, divorced/separated, widowed), as well as interactions between age, sex, and race/ethnicity. Information on one or more demographic characteristic is not reported for 0.8 percent of respondents (8298 persons). To avoid deleting these individuals from the sample, the relevant regressors were set to zero and missing value dummy variables were created. ${ }^{23}$ Finally, the sum of the state and federal taxes (in \$1999) on a case of beer (24-12 ounce cans or bottles) are held constant, using data from various issues of the U.S. Brewers' Association Brewer's Almanac and the Federation of Tax Administrators web-site. ${ }^{24}$

\subsection{Descriptive Information}

Table 1 presents sample means for selected variables. The first column shows averages for the raw data while the second weights the observations using BRFSS final sampling weights. $^{25}$ Males, young adults, minorities, Hispanics, and currently married individuals are underrepresented in the raw data. Since drinking behavior differs substantially across population groups, analysis of unweighted data may therefore provide unreliable estimates of the average "treatment effect" and sampling weights are incorporated in most of the econometric analysis.

\footnotetext{
22 The data on per capita income are from Bureau of Economic Analysis web-site: http://www.bea.doc.gov/bea/ regional/spi.

${ }^{23}$ For instance, the three education variables were set to zero and the "education not reported" variable assigned as one for individuals not reporting years of schooling.

${ }^{24}$ The URL is: http://www.taxadmin.org/fta/rate/beer.html. Taxes are used because they are largely determined independently of demand shocks, whereas prices reflect the interaction of supply and demand.

${ }^{25}$ The final weights make the data representative of the adult population in the state. They are the product of five components accounting for unequal probabilities of inclusion in the sample due to differences in the number of telephones and adults in the household, and in the probability of selection among the geographic strata included in the survey. Further information on the BRFSS weighting procedure can be obtained from the web-site: www.cdc.gov/nccdphp/brfss/ti-weighting.htm. Remington et al., (1988) provide evidence that weighted estimates from the BRFSS are comparable to those for in person surveys.
} 
Drinking is highly concentrated. Just over half of adults imbibed any alcohol in the last month and those doing so averaged around 21 drinks. Fifty percent of consumers had fewer than 10 drinks, 75 percent less than 25 , and only 5 percent imbibed 80 or more alcoholic beverages. Similarly, fewer than 3 percent of adults claim to have driven after "perhaps having had too much to drink." Moreover, those drinking 25 or more beverages accounted for more than 70 percent of alcohol consumption and those consuming 80 or more beverages were responsible for almost 30 percent of total drinking.

Figure 1 displays the pattern of average unemployment rates and alcohol consumption using quarterly data obtained by taking weighted averages over three-month periods and normalizing by subtracting the sample mean and dividing by the standard deviation; thus, the figure shows fluctuations in terms of standard deviations from the mean. Two points are noteworthy. First, drinking was at relatively low levels during the bad economic times of the early 1990s, suggesting that alcohol use is procyclical. However, since other factors could have been changing simultaneously, a multivariate analysis is needed to confirm this. ${ }^{26}$ Second, unemployment and alcohol consumption both trended down over the sample period. The decline in joblessness resulted from the economic expansion of the middle and late 1990s. The fall in drinking reflects a secular trend continuing virtually unabated since 1981, and therefore is presumably not causally related to reductions in unemployment. ${ }^{27}$ This is dealt with in the empirical analysis by including a vector of state-specific time trends.

\section{$\underline{2.4 \text { Econometric Methods }}$}

The basic econometric specification is:

$$
Y_{i j m t}=\alpha_{j}+X_{i j m t} \beta+E_{m j t} \gamma+\delta_{m}+\varepsilon_{i j m t}
$$

\footnotetext{
${ }^{26}$ For instance, the Federal tax on beer was doubled (from $\$ 9$ to $\$ 18$ per barrel) on January 1, 1991.

${ }^{27}$ Apparent per capita ethanol consumption fell 21 percent between 1981 and 1997, primarily due to a 38 percent drop in the drinking of distilled spirits (Nephew et al., 1999).
} 
where $\mathrm{Y}$ is the alcohol outcome for individual $\mathrm{i}$ living in state $\mathrm{j}$ interviewed in month $\mathrm{m}$ of year $\mathrm{t}$, $\mathrm{X}$ is a vector of covariates (individual characteristics and beer taxes), $\mathrm{E}$ the measure of local economic conditions, $\varepsilon$ is a regression disturbance, and $\alpha$ and $\delta$ represent unobserved determinants of alcohol use associated with the state and survey month.

The month-effects control for seasonal variations in alcohol use and the state fixed-effect holds constant determinants of drinking that differ across locations but are time-invariant. The impact of the macroeconomic fluctuations is therefore identified by within-state variations in economic conditions, relative to changes occurring in other states. Most of the models also include a vector of state-specific linear time trends $\left(\alpha_{\mathrm{j}}^{*} \mathrm{~T}\right)$, to control for factors that vary over time within states, implying the regression equation:

$$
Y_{i j m t}=\alpha_{j}+X_{i j m t} \beta+E_{m j t} \gamma+\delta_{m}+\alpha_{j}{ }^{*} T+\varepsilon_{i j t .}{ }^{28}
$$

For ease of interpretation, the results of linear probability models are usually presented for the dichotomous outcomes; however, very similar predicted effects are obtained from corresponding binary probit models. The Huber-White sandwich estimator is used to calculate robust standard errors, with observations assumed to be independent across states and calendar months but not within states in a given month. ${ }^{29}$

\section{Drinking Is Procyclical}

Table 2 summarizes alternative econometric estimates of the effect of a one percentage point increase in the state unemployment rate on drinking participation, conditional drinking, and alcohol-involved driving. ${ }^{30}$ The first three columns differ according to whether or not they include state-specific time trends or weight the data. These models also control for individual

\footnotetext{
${ }^{28}$ The linear time trend measures the number of months elapsed since January 1987.

${ }^{29}$ This procedure is chosen because unemployment rates are the same across all observations in a given statemonth-year cell. For drinking participation and conditional drinking it typically yields standard errors that are 25 to 35 percent larger than those obtained assuming that all observations are independent; the estimated standard errors for alcohol-involved driving are essentially unchanged.

${ }^{30} \mathrm{~A}$ one percentage point increase in unemployment corresponds to a 17 percent ( 0.62 standard deviation) rise from the sample mean value of 5.85 percent.
} 
characteristics, beer taxes, month dummy variables, and state fixed-effects. The parameter

estimates for the supplementary regressors are consistent with those found in previous research (see Appendix Table A.1 for details). ${ }^{31}$

The three specifications consistently indicate that drinking participation is insensitive to macroeconomic conditions, that conditional drinking exhibits a sharp procyclical variation, and suggest that drunk-driving also becomes less common in bad times. The model we prefer, because it includes state-specific trends and sampling weights, and will focus on throughout the remainder of the paper is shown in column (c). ${ }^{32}$ In this case, a one percentage point rise in unemployment is predicted to reduce drinking participation, conditional drinking, and alcoholinvolved driving by $0.3,3.1$, and 3.3 percent respectively. ${ }^{33}$

Model (d) adds a vector of year dummy variables to control for unobserved factors that vary over time but have uniform effects across locations. Unfortunately, the year-effects absorb most of the remaining variation in state unemployment rates, making it difficult to independently identify the impact of the macroeconomy. ${ }^{34}$ Given this, it is no surprise that their inclusion substantially attenuates the predicted impacts - by almost one-half for alcohol-involved driving and over two-thirds for conditional drinking. However, the point estimates continue to suggest a procyclical variation in alcohol use.

31 For instance, females, minorities, and married persons drink relatively little while college graduates have high rates of drinking participation but tend to consume moderate amounts and seldom engage in alcohol-involved driving; beer taxes are negatively correlated with alcohol use.

${ }^{32}$ Weighting may reduce efficiency if sampling is based on exogenous variables and the conditional distribution is correctly specified. However, in our data these conditions do not hold (e.g. because men drink more than women and are underrepresented), implying that weighting is likely to be required to obtain consistent estimates of the average treatment-effect (Wooldridge, 1999; Butler, 2000).

${ }^{33}$ Percentage changes in drinking participation and alcohol-involved driving are calculated at the sample mean values (52.1 and 2.7 percent). Virtually identical estimated effects are obtained when deleting from the sample the three years $(1994,1996$, and 1998) where the alcohol questions are included in optional modules and so are not asked of all respondents.

${ }^{34}$ The year variables eliminate 60.3 percent of the variation in unemployment rates remaining after including month dummy variables, state fixed-effects, and state-specific time trends. By contrast, the addition of state time-trends absorbed just 27 percent of the variation remaining after controlling for month and state fixed-effects. 
Binary probit models are used for the two dichotomous outcomes (drinking participation and alcohol-involved driving) in column (e). The resulting predicted effects, calculated with the explanatory variables other than unemployment evaluated at the sample means, are very close to the corresponding linear probability model estimates, suggesting that little is lost by not explicitly accounting for the discrete nature of these dependent variables.

The estimates in specification (f) use state-level aggregates, constructed by calculating average values for each state-year cell from the (weighted) individual BRFSS data. The alcohol outcome is then regressed on unemployment rates, beer taxes, state fixed-effects, and statespecific time trends, with observations weighted by the square root of the adult population in the state. Thus, these models approximately correspond to previous research (e.g. Ruhm, 1995; Freeman, 1999) examining the macroeconomic variation in state alcohol sales or traffic fatalities with aggregate data. Our findings once again indicate a procyclical pattern of conditional drinking and possibly drunk-driving combined with little change in drinking participation, suggesting that individual and aggregate data yield consistent predictions.

Additional estimates are provided in Table 3. The first column repeats the results of model (c) in Table 2. The next two specifications add controls for the monthly U.S. unemployment rate (model b) or average survey year per capita incomes in the state (column c). The coefficients on the national unemployment rate must be interpreted cautiously, since omitted variables may be spuriously correlated with this measure of macroeconomic conditions. Noting this caveat, specification (b) indicates that national downturns are associated with larger reductions in drinking than corresponding deteriorations in state economic conditions. A one percentage point rise in the U.S. unemployment rate is anticipated to decrease conditional drinking by over 6 percent, drinking participation by 1.6 percentage points $(3.1$ percent $)$, and alcohol-involved driving by 0.15 points ( 5.6 percent); the same rise in state joblessness (controlling for the national rate) is predicted to reduce conditional drinking by just 1.3 percent 
while having no impact on the other two outcomes. This raises the possibility that the withinstate variations focused upon in this analysis understate the reduction in alcohol use occurring during national downturns.

Alcohol consumption falls in bad times partly because of declining incomes. A $\$ 1000$ reduction in per capita personal income is predicted to decrease conditional drinking by over five percent (model c), and controlling for income reduces the unemployment coefficient by around one-quarter. ${ }^{35}$ The $\$ 1000$ decline is also anticipated to lower alcohol-involved driving by 0.12 percentage points (4.4 percent). These results accord with evidence presented by Ruhm (1995) and others that alcohol use and drunk-driving are normal goods.

\section{Light Versus Heavy Drinking}

The findings above demonstrate that the macroeconomic variation in drinking is dominated by changes at the intensive margin (how much drinkers consume) rather than the extensive margin (whether they drink at all). We next consider fluctuations in light and heavy drinking vary by limiting the sample to alcohol users and analyzing dichotomous variables for consumption of $1-10,1-20,21-59, \geq 60$, and $\geq 100$ drinks in the last 30 days. The 60 and 100 (10 and 20) drink cutoffs represent alternative measures of heavy (light) drinking. Although 60 drinks per month (which is frequently used to delineate "chronic" drinking), corresponds to an average of only two alcoholic beverages per day, only 8 percent of consumers (4 percent of all adults) report drinking this much. Similarly fewer than 3 percent of imbibers claim to have consumed 100 or more drinks. Thus, these indicators capture the upper tail of the distribution of alcohol use. A final binary outcome, binge drinking, indicates the consumption of 5 or more

\footnotetext{
${ }^{35}$ To put these results in perspective, $\$ 1000$ represents a 0.28 standard deviation change in income. A one percentage point rise in the state unemployment rate is predicted to decrease per capita incomes by $\$ 640$ (in a regression that also controls for state and month effects).
} 
alcoholic beverages on a single occasion. Binge drinking could occur without heavy alcohol use over the course of a month, although this is uncommon in our data. ${ }^{36}$

The econometric results, displayed in Table 4, demonstrate that alcohol use falls in bad economic times because of reductions in heavy drinking. A one percentage point increase in unemployment decreases the expected probability of consuming 60 (100) or more drinks by 0.63 (0.28) percentage points or $7.8(9.7)$ percent. Small declines in moderate consumption and binge drinking are also observed but there is a statistically significant 2.0 (1.3) percent rise in the likelihood of imbibing 10 (20) or fewer drinks. Once again a portion of the macroeconomic fluctuation is due to changes in incomes; a $\$ 1000$ reduction is predicted to decrease the probability of consuming 60 (100) or more alcoholic beverages by $6.8(1.7)$ percent and to cut binge drinking by 4.7 percent, while raising the frequency of light drinking.

These estimates, combined with those in the previous section, indicate that alcohol use falls during contractions because some drinkers switch from heavy to more moderate levels of consumption, rather than because recreational users give up liquor or reduce their intake. Since heavy drinking is associated with alcohol abuse and light consumption may have medical benefits, it is almost certain that drinking problems become less common in bad times. ${ }^{37}$

\section{Dynamics}

Economic conditions have been assumed to have only a contemporaneous impact on alcohol use until now. Information on the dynamics of the adjustment process is provided in Table 5. Models that include eighteen month lags of the state unemployment rate were estimated and the predicted impact of a one percentage point rise in joblessness that has been sustained for

\footnotetext{
${ }^{36}$ Binge drinkers consumed almost 4 times as many alcoholic beverages during the last month as non-bingers (44 versus 12), were 11 times as likely to have imbibed more than 60 drinks (21.1 versus 1.9 percent), 23 times as often consumed more than 100 beverages ( 8.1 versus 0.4 percent), and 15 times as frequently had driven under the influence (15.5 versus 1.0 percent). Conversely, only 16 (36) percent imbibed $10(20)$ or fewer drinks in the last month, compared with 67 (83) percent of non-binge consumers of alcohol.

37 These findings indicate that Dee's (forthcoming) analysis, because it focuses so heavily on binge drinking, misses important components of heavy alcohol use.
} 
$\mathrm{k}$ months calculated as $\sum_{\mathrm{n}=0}^{\mathrm{k}} \hat{\beta}_{\mathrm{t}-\mathrm{n}}$, for $\hat{\beta}_{\mathrm{t}-\mathrm{n}}$ the regression coefficient on the $\mathrm{n}$-month lag of unemployment. Figure 2 provides additional detail on the adjustment paths, with solid lines indicating predicted effects and dotted lines the 95 percent confidence intervals. Here, and throughout the remainder of the analysis, heavy alcohol use refers to conditional drinking of 100 or more alcoholic beverages in the prior month.

The adjustment patterns exhibit some instability over time, leading to imprecise estimates. Two patterns nevertheless emerge. First, a sustained rise in joblessness is associated with a short-lasting reduction in drinking participation. Thus, a persistent one point increase in unemployment is predicted to reduce drinking participation by $1.3,1.3,0.9$, and 0.5 percentage points $(2.6,2.6,1.8,0.9$ percent $)$ after $0,3,6$, and 9 months but is associated with very small and statistically insignificant changes beyond one year. ${ }^{38}$ The decline in alcohol-involved driving also appears to be temporary, with negative impacts expected in most of the first nine months but essentially no effect thereafter. Second, there are long-lasting changes in alcohol use at the intensive margin. For instance, conditional drinking is predicted to fall 3.4, 3.7, 6.0, and 5.0 percent after $0,3,9$, and 15 months, and heavy consumption (100 or more drinks) by $0.4,0.4$, 0.6 , and 0.4 percentage points $(14.1,12.8,21.7,14.1$ percent $)$. It is noteworthy that we uncover no evidence of larger permanent than transitory effects, as predicted by Becker and Murphy's (1988) theory of rational addiction.

\section{Population Subgroups}

We next test for differences across population subgroups. Males drink much more than females. As shown in Table 6, they are almost 40 percent more likely to have consumed alcohol in the past month and have engaged in alcohol-involved driving 3.6 times as frequently.

Conditional on use, they consume twice as much alcohol, are 5.6 times as likely to have imbibed

\footnotetext{
${ }^{38}$ Similar evidence of larger short-run than long-run changes in alcohol consumption has been obtained by previous researchers examining the effects of treatment programs (Humphreys et al., 1997), divorce (Hartford et al., 1994), DUI-legislation (Ross, 1984), and the privatization of alcohol sales (Mulford et al., 1992).
} 
100 or more beverages, and binge drink 2.3 times as often. Drinking also declines with age and non-Hispanic minorities consume less alcohol than whites. These patterns are consistent with those found in other research (e.g. see U.S. Department of Health and Human Services, 1997).

Table 7 summarizes the econometric results for subsamples stratified by sex, age, and race/ethnicity. A strong procyclical variation in conditional drinking and heavy consumption is observed for most groups, with weaker impacts for drinking participation and alcohol-involved driving. One exception is that non-whites and senior citizens are more likely than others to stop drinking altogether during economic downturns. The large cyclical variation in alcohol use by Hispanics is also noteworthy. A one point rise in unemployment is predicted to reduce their conditional drinking by 5.8 percent and alcohol-involved driving or heavy drinking by more than 15 percent. The specific employment patterns of Hispanics (e.g. their high representation in agricultural jobs) could play a role, as could cultural considerations. ${ }^{39}$

The adjustment to sustained changes in economic conditions was examined using the same procedures as above. The results, briefly summarized in Appendix Table A.2, indicate similar time profiles whereby a sustained rise in joblessness leads to temporary reductions in expected drinking participation and alcohol-involved driving but longer-lasting decreases in conditional drinking and heavy alcohol consumption. There is, however, substantial variation in the magnitudes of the estimated effects across population subgroups.

\section{Recession-Induced Unemployment}

A decline in overall drinking during bad times could mask increased consumption among persons entering unemployment. We investigate this possibility using the augmented regression model:

$$
Y_{i j m t}=\alpha_{j}+X_{i j m t} \beta+E_{m j t} \gamma+\delta_{m}+\alpha_{j}^{*} T+U_{i j m t} \phi+U_{i j m t} E_{m j t} \lambda+\varepsilon_{i j t}
$$

\footnotetext{
${ }^{39}$ For example, previous research suggests that Hispanics often consume alcohol as a reward for hard work (Heath, 1995; Ames and Rebhun, 1996)
} 
where E now represents the deviation of the state unemployment rate from the sample mean and

$\mathrm{U}$ is a dummy variable set to one for respondents reporting their labor force status as "out of work for less than 1 year." $" 40$ Persons "employed for wages" or "self-employed" are the reference group and exposition of the results is simplified by excluding nonparticipants, defined as those whose status is "homemaker", "student", "retired", "unable to work", or "out of work for more than 1 year." We further restrict the analysis to 25 to 55 year olds (who are of prime working age) and pay special attention to males, since nonparticipation is rare for men of this age.

Subject to a caveat discussed below, $\hat{\gamma}$ measures the impact of macroeconomic conditions on employed persons, $\hat{\phi}$ indicates the average difference in drinking between jobless individuals and workers, and $\hat{\lambda}$ (the coefficient of primary interest) shows how this disparity fluctuates with economic conditions. Specifically, if economic downturns lead to higher alcohol consumption by the newly unemployed, despite an overall reduction in use, $\hat{\lambda}$ will be positive and larger in magnitude than the negative value of $\hat{\gamma}$.

There is no evidence of increased drinking among persons becoming jobless during bad times. Column (a) of Table 8 shows results for the model estimated previously (equation 4), while specification (b) provides the augmented regression estimates (equation 5). The interaction coefficient is almost always negative, suggesting larger procyclical variations in alcohol use for recently unemployed individuals than for workers. A one percentage point increase in state unemployment is predicted to reduce the conditional drinking of employed 2555 year old males by 3.9 percent, compared to an almost 6 percent decrease for those out of work

\footnotetext{
${ }^{40}$ The transformation of the state unemployment rate is used so that the coefficient on the individual labor market status variable can be interpreted as the predicted effect at the mean state unemployment rate.

41 Almost all of those "out of work for more than 1 year" are likely to be nonparticipants using official definitions. For instance, Current Population Survey data reveals that just 10 percent of those unemployed in 1990 had been so for more than six months, whereas more than 45 percent of "out of work" 1990 BRFSS respondents claimed to have been jobless for more than one year. The labor force participation rate in 1990 was 66.7 percent in the CPS data; similarly, 66.4 percent of respondents to the 1990 BRFSS were nonparticipants when this category includes those "out of work for more than 1 year." We also estimated models that include these nonparticipants. (These regression equations contain additional intercept and interaction terms.) Doing so does not materially change the findings.
} 
less than a year. ${ }^{42}$ Similarly, a 0.4 percentage point decline in heavy drinking is anticipated for the former group versus a 1.4 point drop among the latter. Negative interaction terms are also generally obtained for females, although the magnitudes are smaller. This is expected since women drink less (than men) and the distinction between nonparticipation and unemployment is sometimes more ambiguous for them.

An alternative explanation of these findings deserves mention. Positive values of $\hat{\phi}$ imply that persons out of work less than a year typically consume more alcohol than their employed counterparts. $^{43}$ This is expected if heavy alcohol use makes it harder to find or hold jobs. If the distribution of joblessness becomes more random when the economy deteriorates (e.g. as firms engage in non-selective mass layoffs), negative interaction coefficients might then reflect positive selection into unemployment during bad times, rather than a causal impact of the macroeconomy. Without longitudinal data, it is difficult to separate such compositional effects from changes in behavior and our results must be interpreted with caution. Notwithstanding this, we uncover no evidence that loss of employment during bad times is associated with increased drinking. Instead, the data suggest relatively large declines for this group.

\section{Conclusion}

This investigation uses microdata to confirm that drinking decreases in bad economic times and expands on previous analyses by providing four new findings. First, almost all of the procyclical variation is due to changes in the consumption of existing drinkers with, at most, short-lasting movements into or out of alcohol use. Second, the decrease in consumption during downturns is concentrated among heavy rather than recreational drinkers. Since heavy use is associated with alcohol problems and light drinking may yield health benefits, these results provide strong evidence that alcohol abuse is procyclical. Third, the macroeconomic responses

\footnotetext{
${ }^{42}$ This is calculated as: $\exp [(-.0393)+(-.0203)]-1=-.058$.
} 
tend to be relatively similar across demographic categories but with relatively large cyclical

fluctuations observed for groups with high average levels of drinking and Hispanics. Fourth, there is suggestive (but not conclusive) evidence that recent job losers, as well as those remaining employed, cut their consumption when the economy deteriorates.

The results have important implications. While we can not rule out the possibility that the stress of a deteriorating economy causes some individuals to self-medicate by increasing alcohol use, any such effect is more than offset by broader reductions in overall drinking. One reason for the fall in consumption is that incomes decline and alcohol is a normal good. It is therefore not surprising that the decrease is concentrated among heavy drinkers, who spend the most on liquor. Nevertheless, it is noteworthy that this apparently dominates any resistance to decreasing consumption due to the potentially addictive nature of substantial alcohol use.

The failure to adequately account for the macroeconomic environment could also result in biased estimates of the social costs of alcohol problems calculated using data from a single point in time. For instance, one frequently cited study concludes that alcohol abuse cost the U.S. \$148 billion in 1992 (U.S. Department of Health and Human Services, 1998). However, given the weak economy in that year (e.g. the unemployment rate was 7.5 percent), these figures may understate the expenses in more robust periods, such as the middle and late $1990 \mathrm{s.}^{44}$

\footnotetext{
${ }^{43}$ Working 25-55 year old men imbibed an average of 26 alcoholic beverages in the month prior to the survey, compared to 34 drinks for corresponding men out of work for less than a year. Similarly, 3.7 percent of the former group drank heavily (over 100 drinks) versus 7.1 percent of the latter.

44 The 1992 figures also do not account for price changes or population growth occurring since that time. Conversely, there are numerous reasons why these estimates might overstate the costs of alcohol use. For instance, almost half of the expense is attributed to lost earnings due to "impaired productivity", even though the empirical evidence linking alcohol use to reduced wages is weak. 


\section{References}

Ames, Genevieve M., and L.A. Rebhun. 1996. "Women, Alcohol, and Work: Interactions of Gender, Ethnicity, and Occupational Culture", Social Science and Medicine, 43(11), 16491663.

Baker, Dean B. 1985. "The Study of Stress at Work” Annual Review of Public Health, 6, 367-81.

Becker, Gary S. and Kevin M. Murphy. 1988. "A Theory of Rational Addiction”, Journal of Political Economy, 96(4), 675-700.

Brenner, M. Harvey and Anne Mooney. 1983. "Unemployment and Health in the Context of Economic Change” Social Science Medicine, 17(16), 1125-1138.

Butler, J.S. 2000. "Efficiency Results of MLE and GMM Estimation With Sampling Weights", Journal of Econometrics 96, 25-37.

Catalano, Ralph, David Dooley, Georjeanna Wilson, and Richard Hough. 1993. "Job Loss and Alcohol Abuse: A Test Using Data from the Epidemiologic Catchment Area Project”, Journal of Health and Social Behavior, 34(3), 215-225.

Cook, Philip J. and Michael J. Moore. 2000. "Alcohol” in Anthony J. Culyer and Joseph P. Newhouse (eds.) Handbook of Health Economics. Amsterdam: Elsevier, 1630-1673.

Cook, Philip J. and George Tauchen. 1982. "The Effect of Liquor Taxes on Heavy Drinking" Bell Journal of Economics 3, 379-90.

Dee, Thomas S. Forthcoming. 2001. "Alcohol Abuse and Economic Conditions: Evidence From Repeated Cross-Sections of Individual-Level Data", Health Economics, 10(3), 257270.

Ettner, Susan L. 1997. "Measuring the Human Cost of A Weak Economy: Does Unemployment Lead to Alcohol Abuse?", Social Science Medicine, 44(2), 251-260.

Evans William and John D. Graham. 1988. "Traffic Safety and the Business Cycle" Alcohol, Drugs, and Driving 4, 31-8.

Feather, Norman T. 1990. The Psychological Impact of Unemployment. New York: SpringerVerlag.

Fenwick, Rudy and Mark Tausig. 1994. "The Macroeconomic Context of Job Stress", Journal of Health and Social Behavior, 35(3), 266-282.

Freeman, Donald G. 1999. "A note on 'Economic Conditions and Alcohol Problems"”, Journal of Health Economics, 18(5), 661-670.

Gaziano, J. Michael, Julie E. Buring, Jan L. Breslow, Samuel Z. Goldhaber, Bernard Rosner, Martin VanDenburgh, Walter Willett, Charles H. Hennekens. 1993. "Moderate Alcohol 
Intake, Increased Levels of High-Density Lipoprotein and Its Subfractions, and Decreased Risk of Myocardial Infarction” New England Journal of Medicine 329, 1829-1834.

Gruenewald, Paul J. 1993. "Alcohol Problems and the Control of Availability: Theoretical and Empirical Issues" in Michael Hilton and Gregory Bloss (eds.) Economics and the Prevention of Alcohol Related Problems. Rockville, MD: National Institute of Alcohol Abuse and Alcoholism, 59-90.

Hartford, Thomas C., Eleanor A. Hanna, and Vivian B. Faden. 1994. "The Long- and ShortTerm Effects of Marriage on Drinking”, Journal of Substance Abuse, 6, 209-217.

Heath, Dwight B. 1995. International Handbook of Alcohol and Culture. London: The Greenwood Press.

Humphreys, Keith, Rudolf H. Moos, and Caryn Cohen. 1997. "Social and Community Resources and Long-Term Recovery from Treated and Untreated Alcoholism", Journal of Studies on Alcohol, 58(3), 231-238.

Johnston, Lloyd D., Patrick M. O’Malley, and Jerald G. Bachman., eds. 1992. Smoking, Drinking, and Illicit Drug Use Among American Secondary School Students, College Students, and Young Adults, 1975-1991. Vol. II: College Students and Young Adults. NIH publication No. 93-3481. Rockville, MD: National Institute on Drug Abuse.

Karasek, Robert A. and Töres Theorell. 1990. Healthy Work: Stress, Productivity, and the Reconstruction of Working Life. New York: Basic Books.

Kenkel, Donald S. 1996. "New Estimates of the Optimal Tax on Alcohol" Economic Inquiry 34, 296-319.

Manning, Willard G., Linda Blumberg, and Lawrence H. Moulton. 1995. "The Demand for Alcohol: The Differential Response to Price" Journal of Health Economics 14, 123-148.

Midanik, Lorraine T. 1982. "The Validity of Self-Reported Alcohol Consumption and Alcohol Problems: A Literature Review", British Journal of Addiction, 77, 357-382.

Mulford, H.A., J. Ledolter, and J.L. Fitzgerald. 1992. "Alcohol Availability and Consumption: Iowa Sales Data Revisited”, Journal of Studies on Alcohol, 53(5), 487-494.

Mullahy, John. 1998. "Much Ado About Two: Reconsidering Retransformation and the TwoPart Model in Health Econometrics", Journal of Health Economics, 17(3), 247-281.

Nephew, Thomas M., Gerald D. Williams, Frederick S. Stinson, Kim Ngyen, Mary C. Dufour. 1999. Surveillance Report \#51: Apparent Per Capita Alcohol Consumption: National, State, and Regional Trends, 1977-97. Bethesda, MD: National Institute on Alcohol Abuse and Alcoholism.

O'Neill, Brian. 1984. "Recent Trends in Motor Vehicle Crash Deaths" American Association for Automotive Medicine 6, 29-32. 
Pierce, Robert S., Michael R. Frone, Marcia Russell, and M. Lynne Cooper. 1994. "Relationship of Financial Strain and Psychosocial Resources to Alcohol Use and Abuse: The Mediating Role of Negative Affect and Drinking Motives" Journal of Health and Social Behavior, 35(4), 291-308.

Remington Patrick L., Meredith Y. Smith, David F. Williamson, Robert F. Anda, Eileen M. Gentry, and Gary C. Hogelin. 1988. Design, Characteristics, and Usefulness of State-Based Behavioral Risk Factor Surveillance 1981-1986. Public Health Reports, 103(4), 366-75.

Ross, Laurence H. 1984. "Social Control Through Deterrence: Drinking-and-Driving Laws", Annual Review of Sociology, 10, 21-35.

Ruhm, Christopher J. 1995. "Economic Conditions and Alcohol Problems", Journal of Health Economics, 14(5), 583-603.

Ruhm, Christopher J. 2000. “Are Recessions Good for Your Health?”, Quarterly Journal of Economics, 115(2), 617-650.

Skog, Ole-Jorgen. 1986. "An Analysis of Divergent Trends in Alcohol Consumption and Economic Development” Journal of Studies on Alcohol 47, 19-25.

Sloan, Frank A., Bridget A. Reilly, and Christoph Schenzler. 1995. "Effects of Tort Liability and Insurance on Heavy Drinking and Drinking and Driving” Journal of Law and Economics 38, 49-78.

Sokejima, Shigeru and Sadanobu Kagamimori. 1998 "Working Hours as a Risk Factor for Acute Myocardial Infarction in Japan: A Case-Control Study" The British Medical Journal, 317 (September 19), 775-780.

Theodossiou, I. 1998. "The Effects of Low-Pay and Unemployment on Psychological WellBeing: A Logistic Regression Approach” Journal of Health Economics 17, 85-104.

Thun, Michael J., Richard Peto, Alan D. Lopez, Jane H. Monaco, S. Jane Henley, Clark W. Heath Jr., and Richard Doll. 1997. "Alcohol Consumption and Mortality Among MiddleAged and Elderly U.S. Adults” New England Journal of Medicine 337(24), 1705-1714.

U.S. Department of Health and Human Services. 1997. "Epidemiology of Alcohol Use and Alcohol-Related Consequences" in $9^{\text {th }}$ Special Report to Congress on Alcohol and Health (NIH Publication No. 97-4017). Bethesda, MD: National Institutes of Health, 1-31.

U. S. Department of Health and Human Services. 1998. The Economic Costs of Alcohol and Drug Abuse in the United States, 1992. Rockville, MD: Public Health Service.

U.S. Department of Health and Human Services. 2000. "Effect of Changes in Alcohol Taxes and Prices" in $10^{\text {th }}$ Special Report to Congress on Alcohol and Health (NIH Publication No. 00-1583). Bethesda, MD: National Institutes of Health, 341-354.

Wagenaar, Alexander C. and Frederick M. Streff. 1989. "Macroeonomic Conditions and Alcohol-Impaired Driving” Journal of Studies on Alcohol, 50, 217-25. 
Wagenaar, Alexander C. 1993. "Minimum Drinking Age and Alcohol Availability to Youth: Issues and Research Needs" in Michael Hilton and Gregory Bloss (eds.) Economics and the Prevention of Alcohol Related Problems. Rockville, MD: National Institute of Alcohol Abuse and Alcoholism, 175-200.

Winton, Maurice, Nick Heather, and Ian Robertson. 1986. "Effects of Unemployment on Drinking Behavior: A Review of the Relevant Evidence" The International Journal of Addictions, 21(12), 1261-1283.

Wooldridge, Jeffrey. 1999. “Asymptotic Properties of Weighted M-Estimators for Variable Probability Samples, Econometrica, 67(6), 1385-1406. 
Table 1:

Sample Means for Variables Used in Analysis

\begin{tabular}{|c|c|c|}
\hline Variable & Unweighted Mean & Weighted Mean \\
\hline \multicolumn{3}{|l|}{ Alcohol Use in Last Month } \\
\hline Drinker (any use) & .496 & .521 \\
\hline \# Drinks (top-coded at 450) & 19.7 & 21.4 \\
\hline Alcohol-Involved Driving & .024 & .027 \\
\hline Age (years) & 46.1 & 44.1 \\
\hline Female & .582 & .520 \\
\hline Employed (at survey date) & .619 & .626 \\
\hline \multicolumn{3}{|l|}{ Race/Ethnicity } \\
\hline Black & .085 & .096 \\
\hline Other Nonwhite & .052 & .058 \\
\hline Hispanic Origin & .053 & .089 \\
\hline Race Not Reported & .003 & .002 \\
\hline Hispanic Origin Not Reported & .003 & .003 \\
\hline \multicolumn{3}{|l|}{ Education } \\
\hline High School Dropout & .148 & .154 \\
\hline Some College & .256 & .254 \\
\hline College Graduate & .262 & .256 \\
\hline Education Not Reported & .002 & .002 \\
\hline \multicolumn{3}{|l|}{ Current Marital Status } \\
\hline Married/Cohabiting & .572 & .628 \\
\hline Divorced/Separated & .146 & .106 \\
\hline Widowed & .110 & .074 \\
\hline Marital Status Not Reported & .002 & .001 \\
\hline \multicolumn{3}{|l|}{ State-Level Variables } \\
\hline Survey Month Unemployment Rate (\%) & 5.42 & 5.85 \\
\hline Personal Income (thousands of \$1999) & 24.9 & 25.6 \\
\hline Beer Tax per Case $(\$ 1999)$ & 1.92 & 1.85 \\
\hline
\end{tabular}

Note: Data are from the 1987-1999 years of the BRFSS, with additional information on state economic conditions and beer taxes merged in from other sources. The table shows mean values of variables used in the econometric analysis. The first column shows unweighted averages; the second column weights the observations using BRFSS final sampling weights. 
Table 2: Predicted Effect of A One Percentage Point Increase in the State Unemployment Rate on Alcohol Use and Problems

\begin{tabular}{|c|c|c|c|c|c|c|}
\hline Outcome & (a) & (b) & (c) & (d) & (e) & (f) \\
\hline Drinker & $\begin{array}{c}-.0004 \\
(.0008)\end{array}$ & $\begin{array}{l}-.0006 \\
(.0008)\end{array}$ & $\begin{array}{c}-.0018 \\
(.0013)\end{array}$ & $\begin{array}{c}.0019 \\
(.0013)\end{array}$ & $\begin{array}{l}-.0021 \\
(.0014)\end{array}$ & $\begin{array}{c}-.0003 \\
(.0031)\end{array}$ \\
\hline Log of Number of Drinks & $\begin{array}{c}-.0151 \\
(.0024)\end{array}$ & $\begin{array}{c}-.0184 \\
(.0027)\end{array}$ & $\begin{array}{c}-.0313 \\
(.0048)\end{array}$ & $\begin{array}{c}-.0099 \\
(.0045)\end{array}$ & ---- & $\begin{array}{l}-.0408 \\
(.0141)\end{array}$ \\
\hline Alcohol-Involved Driving & $\begin{array}{c}-.0004 \\
(.0002)\end{array}$ & $\begin{array}{l}-.0002 \\
(.0002)\end{array}$ & $\begin{array}{c}-.0009 \\
(.0003)\end{array}$ & $\begin{array}{l}-.0005 \\
(.0004)\end{array}$ & $\begin{array}{l}-.0006 \\
(.0002)\end{array}$ & $\begin{array}{l}-.0007 \\
(.0005)\end{array}$ \\
\hline Type of Data & Individual & Individual & Individual & Individual & Individual & Aggregate \\
\hline State-Specific Time-Trends & No & Yes & Yes & Yes & Yes & Yes \\
\hline Year Effects & No & No & No & Yes & No & No \\
\hline Sampling Weights & No & No & Yes & Yes & Yes & Yes \\
\hline Estimation Technique & OLS & OLS & WLS & WLS & Probit & WLS \\
\hline
\end{tabular}

Note: Table shows predicted effects of a one percentage point increase in the state unemployment rate, using data from the 1987-1999 BRFSS. The first five columns show results using individual-level data. Robust standard errors, calculated assuming that observations are independent across months and states but not within states in a given month, are reported in parentheses. These specifications include month and state dummy variables and control for beer taxes, age, sex, race/ethnicity, education, marital status, interactions between age, sex, and race/ethnicity. Columns (b) through (e) also contain state-specific linear time trends and specification (d) includes year dummy variables. "Drinking" refers to a dichotomous variable indicating whether the respondent had at least one drink in the last month. The "number of drinks" refers to the quantity of drinks in the last month for those with some consumption. Alcohol-involved driving is a binary variable set to one if the respondent reported driving at least once during the last month when he/she "had perhaps to much to drink".

Sample sizes are 1,032,965, 490,653, and 1,030,174 for the three outcomes. Appendix Table A.1 presents additional coefficient estimates for specification (a). Predicted effects are equal to the unemployment rate coefficients for the OLS and WLS estimates. For the probit models they are calculated as the marginal effects with the independent variables, other than the unemployment rate, evaluated at the sample means. Column (f) shows the results of models estimated by regressing state level aggregates on the state unemployment rate, beer tax, state dummy variables, and state-specific time trends. These data are obtained by taking (weighted) averages for each state-year cell in the BRFSS sample. These regressions are estimated using the square root of the adult state population (aged 18 and over) to weight the data. 
Table 3:

Additional Estimates of the Effects of Changes

in Macroeconomic Conditions on Alcohol Use and Drinking Problems

\begin{tabular}{|c|c|c|c|}
\hline Regressor & (a) & (b) & (c) \\
\hline & & Drinker & \\
\hline State Unemployment Rate & $\begin{array}{l}-.0018 \\
(.0013)\end{array}$ & $\begin{array}{c}.0021 \\
(.0013)\end{array}$ & $\begin{array}{c}-.0021 \\
(.0013)\end{array}$ \\
\hline National Unemployment Rate & & $\begin{array}{c}-.0163 \\
(.0025)\end{array}$ & \\
\hline \multirow[t]{2}{*}{ Per Capita Personal Income (\$1000) } & & & $\begin{array}{c}-.0012 \\
(.0023)\end{array}$ \\
\hline & \multicolumn{3}{|c|}{ Log of Number of Drinks } \\
\hline State Unemployment Rate & $\begin{array}{c}-.0313 \\
(.0048)\end{array}$ & $\begin{array}{c}-.0131 \\
(.0050)\end{array}$ & $\begin{array}{c}-.0231 \\
(.0052)\end{array}$ \\
\hline National Unemployment Rate & & $\begin{array}{c}-.0664 \\
(.0095)\end{array}$ & \\
\hline \multirow[t]{2}{*}{ Per Capita Personal Income $(\$ 1000)$} & & & $\begin{array}{c}.0537 \\
(.0080)\end{array}$ \\
\hline & \multicolumn{3}{|c|}{ Alcohol-Involved Driving } \\
\hline State Unemployment Rate & $\begin{array}{l}-.0009 \\
(.0003)\end{array}$ & $\begin{array}{l}-.0005 \\
(.0004)\end{array}$ & $\begin{array}{l}-.0007 \\
(.0004)\end{array}$ \\
\hline National Unemployment Rate & & $\begin{array}{l}-.0015 \\
(.0007)\end{array}$ & \\
\hline Per Capita Personal Income $(\$ 1000)$ & & & $\begin{array}{c}.0012 \\
(.0006)\end{array}$ \\
\hline
\end{tabular}

Note: See note on Table 2. The regressions also control for personal characteristics and beer taxes, month and state dummy variables, state-specific linear time trends, and are estimated by weighted least squares, using BRFSS final sampling weights. Robust standard errors are reported in parentheses. 
Table 4:

Econometric Estimates of Categorical Amounts of Drinking For Persons Consuming Some Alcohol During the Last Month

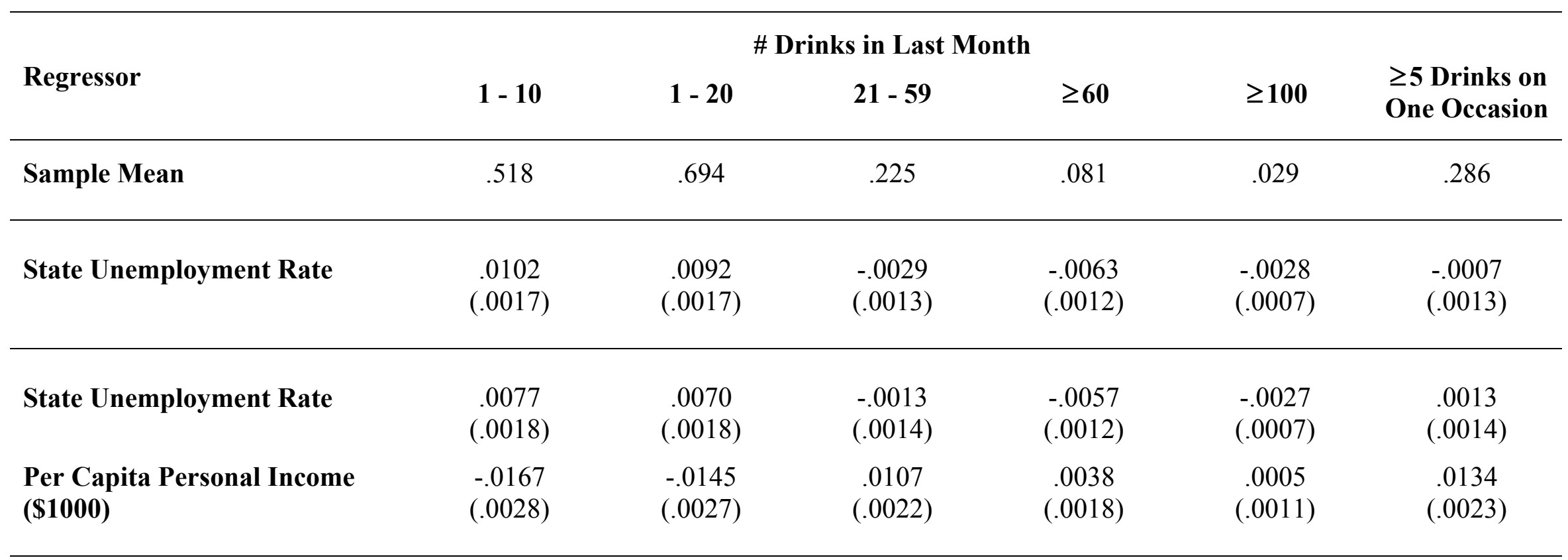

Note: See note on Table 2. All of the dependent variables are dichotomous outcomes indicating whether the respondents consume the specified amounts of alcohol. The sample is restricted to persons with some drinking during the last month. The upper panel shows the weighted mean for each dependent variable. The middle and lower panels show regression results for models which also control for personal characteristics and beer taxes, month and state dummy variables, and state-specific linear time trends. The regressions are estimated by weighted least squares, using BRFSS final sampling weights. Robust standard errors are reported in parentheses. 
Table 5:

Predicted Effect of a Sustained One Percentage Point Increase in the State Unemployment Rate on Alcohol Use and Drinking Problems

\begin{tabular}{|c|c|c|c|c|}
\hline $\begin{array}{l}\text { Months Since Rise in } \\
\text { Unemployment }\end{array}$ & Drinker & $\begin{array}{c}\text { Log of } \\
\text { Number of } \\
\text { Drinks }\end{array}$ & $\begin{array}{c}\text { Alcohol- } \\
\text { Involved } \\
\text { Driving }\end{array}$ & $\begin{array}{c}\text { Heavy } \\
\text { Drinking }\end{array}$ \\
\hline 0 & $\begin{array}{l}-.0133 \\
(.0043)\end{array}$ & $\begin{array}{l}-.0348 \\
(.0159)\end{array}$ & $\begin{array}{l}-.0020 \\
(.0011)\end{array}$ & $\begin{array}{l}-.0041 \\
(.0019)\end{array}$ \\
\hline 3 & $\begin{array}{l}-.0134 \\
(.0040)\end{array}$ & $\begin{array}{l}-.0375 \\
(.0156)\end{array}$ & $\begin{array}{l}-.0038 \\
(.0012)\end{array}$ & $\begin{array}{l}-.0037 \\
(.0021)\end{array}$ \\
\hline 6 & $\begin{array}{l}-.0093 \\
(.0031)\end{array}$ & $\begin{array}{l}-.0270 \\
(.0129)\end{array}$ & $\begin{array}{l}-.0011 \\
(.0009)\end{array}$ & $\begin{array}{l}-.0051 \\
(.0019)\end{array}$ \\
\hline 9 & $\begin{array}{l}-.0047 \\
(.0030)\end{array}$ & $\begin{array}{l}-.0616 \\
(.0127)\end{array}$ & $\begin{array}{l}-.0012 \\
(.0009)\end{array}$ & $\begin{array}{l}-.0063 \\
(.0017)\end{array}$ \\
\hline 12 & $\begin{array}{l}.0048 \\
(.0042)\end{array}$ & $\begin{array}{l}-.0286 \\
(.0160)\end{array}$ & $\begin{array}{l}-.0007 \\
(.0011)\end{array}$ & $\begin{array}{l}-.0020 \\
(.0018)\end{array}$ \\
\hline 15 & $\begin{array}{c}.0031 \\
(.0041)\end{array}$ & $\begin{array}{l}-.0514 \\
(.0157)\end{array}$ & $\begin{array}{l}.0014 \\
(.0011)\end{array}$ & $\begin{array}{l}-.0041 \\
(.0021)\end{array}$ \\
\hline 18 & $\begin{array}{c}.0059 \\
(.0015)\end{array}$ & $\begin{array}{l}-.0180 \\
(.0053)\end{array}$ & $\begin{array}{l}-.0007 \\
(.0004)\end{array}$ & $\begin{array}{l}-.0005 \\
(.0007)\end{array}$ \\
\hline
\end{tabular}

Note: See note on Table 2. This table shows the predicted effect of a one percentage point increase in the state unemployment rate which is sustained for the number of months shown in the first column of the table. These predictions are made using models that correspond to column (c) of Table 2, except that they also include lagged unemployment rates for the first through eighteenth month prior to the survey date. The effect of a rise in the unemployment rate lasting for $\mathrm{k}$ months is calculated as $\sum_{\mathrm{n}=0}^{\mathrm{k}} \hat{\beta}_{\mathrm{t}-\mathrm{n}}$, for $\hat{\beta}_{\mathrm{t}-\mathrm{n}}$ the regression coefficient on the $\mathrm{n}$ month lag of the state unemployment rate. Robust standard errors are shown in parentheses. Heavy drinking is defined as the consumption of 100 or more drinks in the last month, for respondents with some alcohol use. 
Table 6:

Sample Means on Alcohol Outcomes for Population Subgroups

\begin{tabular}{|c|c|c|c|c|c|c|}
\hline Group & Drinker & $\begin{array}{l}\text { Number } \\
\text { of Drinks }\end{array}$ & $\begin{array}{l}\text { Alcohol- } \\
\text { Involved } \\
\text { Driving }\end{array}$ & $\begin{array}{c}\text { Heavy } \\
\text { Drinking }\end{array}$ & $\begin{array}{c}\text { Binge } \\
\text { Drinking }\end{array}$ & $\begin{array}{c}\text { Sample } \\
\text { Size }\end{array}$ \\
\hline Full Sample & .521 & 21.4 & .027 & .028 & .285 & $1,032,965$ \\
\hline \multicolumn{7}{|l|}{ Sex } \\
\hline Male & .608 & 28.0 & .043 & .045 & .378 & 431,902 \\
\hline Female & .440 & 13.0 & .012 & .008 & .166 & 601,063 \\
\hline \multicolumn{7}{|l|}{ Race/Ethnicity } \\
\hline White (Not Hispanic) & .541 & 21.5 & .028 & .028 & .282 & 855,506 \\
\hline Black (Not Hispanic) & .402 & 19.8 & .016 & .028 & .246 & 85,033 \\
\hline Other (Not Hispanic) & .453 & 19.0 & .020 & .029 & .256 & 37,985 \\
\hline Hispanic & .496 & 22.5 & .031 & .035 & .352 & 54,441 \\
\hline \multicolumn{7}{|l|}{ Age (in years) } \\
\hline 18 to 24 & .589 & 26.2 & .054 & .044 & .481 & 101,363 \\
\hline 25 to 64 & .550 & 20.5 & .027 & .026 & .272 & 731,096 \\
\hline$\geq 65$ & .344 & 20.4 & .003 & .023 & .085 & 200,506 \\
\hline
\end{tabular}

Note: Observations are weighted using BRFSS final sampling weights. The number of drinks and the probability of heavy or binge drinking are calculated for persons with some alcohol use during the month. Heavy drinking is defined as the consumption of 100 or more alcoholic beverages. 
Table 7:

Predicted Effect of a One Percentage Point Increase in the State Unemployment Rate on Alcohol Use and Drinking Problems

\begin{tabular}{|c|c|c|c|c|}
\hline Group & Drinker & $\begin{array}{c}\text { Log of } \\
\text { Number of } \\
\text { Drinks }\end{array}$ & $\begin{array}{c}\text { Alcohol- } \\
\text { Involved } \\
\text { Driving }\end{array}$ & $\begin{array}{c}\text { Heavy } \\
\text { Drinking }\end{array}$ \\
\hline All Respondents & $\begin{array}{c}-.0018 \\
(.0013)\end{array}$ & $\begin{array}{c}-.0313 \\
(.0048)\end{array}$ & $\begin{array}{l}-.0009 \\
(.0003)\end{array}$ & $\begin{array}{c}-.0028 \\
(.0007)\end{array}$ \\
\hline \multicolumn{5}{|l|}{ Sex } \\
\hline Male & $\begin{array}{l}-.0020 \\
(.0017)\end{array}$ & $\begin{array}{l}-.0342 \\
(.0062)\end{array}$ & $\begin{array}{l}-.0017 \\
(.0007)\end{array}$ & $\begin{array}{l}-.0042 \\
(.0011)\end{array}$ \\
\hline Female & $\begin{array}{l}-.0018 \\
(.0015)\end{array}$ & $\begin{array}{c}-.0277 \\
(.0055)\end{array}$ & $\begin{array}{l}-.0001 \\
(.0003)\end{array}$ & $\begin{array}{l}-.0011 \\
(.0005)\end{array}$ \\
\hline \multicolumn{5}{|l|}{ Race/Ethnicity } \\
\hline White (Not Hispanic) & $\begin{array}{l}-.0012 \\
(.0013)\end{array}$ & $\begin{array}{c}-.0302 \\
(.0048)\end{array}$ & $\begin{array}{c}-.0005 \\
(.0004)\end{array}$ & $\begin{array}{c}-.0028 \\
(.0007)\end{array}$ \\
\hline Black (Not Hispanic) & $\begin{array}{l}-.0086 \\
(.0037)\end{array}$ & $\begin{array}{l}-.0089 \\
(.0159)\end{array}$ & $\begin{array}{l}-.0012 \\
(.0010)\end{array}$ & $\begin{array}{l}-.0027 \\
(.0026)\end{array}$ \\
\hline Other Race (Not Hispanic) & $\begin{array}{c}-.0158 \\
(.0059)\end{array}$ & $\begin{array}{l}-.0596 \\
(.0247)\end{array}$ & $\begin{array}{l}-.0007 \\
(.0015)\end{array}$ & $\begin{array}{c}.0007 \\
(.0031)\end{array}$ \\
\hline Hispanic & $\begin{array}{c}.0003 \\
(.0046)\end{array}$ & $\begin{array}{c}-.0684 \\
(.0216)\end{array}$ & $\begin{array}{l}-.0047 \\
(.0018)\end{array}$ & $\begin{array}{c}-.0054 \\
(.0027)\end{array}$ \\
\hline \multicolumn{5}{|l|}{ Age (in years) } \\
\hline 18 to 24 & $\begin{array}{l}-.0029 \\
(.0034)\end{array}$ & $\begin{array}{c}-.0276 \\
(.0112)\end{array}$ & $\begin{array}{l}-.0032 \\
(.0015)\end{array}$ & $\begin{array}{l}-.0027 \\
(.0020)\end{array}$ \\
\hline 25 to 64 & $\begin{array}{l}-.0008 \\
(.0014)\end{array}$ & $\begin{array}{c}-.0333 \\
(.0049)\end{array}$ & $\begin{array}{c}-.0006 \\
(.0004)\end{array}$ & $\begin{array}{c}-.0030 \\
(.0007)\end{array}$ \\
\hline$\geq 65$ & $\begin{array}{c}-.0050 \\
(.0023)\end{array}$ & $\begin{array}{c}-.0209 \\
(.0120)\end{array}$ & $\begin{array}{c}-.0002 \\
(.0002)\end{array}$ & $\begin{array}{c}-.0017 \\
(.0013)\end{array}$ \\
\hline
\end{tabular}

Note: See notes on Tables 2 and 5. The regressions control for personal characteristics and beer taxes, month and state dummy variables, and state-specific linear time trends. They are estimated by WLS using BRFSS final sampling weights. Robust standard errors are reported in parentheses. 
Table 8:

Estimates With Interactions Between State Unemployment Rates and Current Labor Market Status for 25-55 Year Olds

\begin{tabular}{|c|c|c|c|c|c|c|c|c|}
\hline \multirow[t]{2}{*}{ Explanatory Variable } & \multicolumn{2}{|c|}{ Drinker } & \multicolumn{2}{|c|}{$\begin{array}{c}\text { Log of } \\
\text { Number of Drinks }\end{array}$} & \multicolumn{2}{|c|}{$\begin{array}{c}\text { Alcohol-Involved } \\
\text { Driving }\end{array}$} & \multicolumn{2}{|c|}{$\begin{array}{c}\text { Heavy } \\
\text { Drinking }\end{array}$} \\
\hline & (a) & (b) & (a) & (b) & (a) & (b) & (a) & (b) \\
\hline & \multicolumn{8}{|c|}{ Males } \\
\hline State Unemployment Rate & $\begin{array}{l}-.0002 \\
(.0020)\end{array}$ & $\begin{array}{l}-1.0 \mathrm{E}-5 \\
(.0020)\end{array}$ & $\begin{array}{l}-.0395 \\
(.0070)\end{array}$ & $\begin{array}{l}-.0393 \\
(.0070)\end{array}$ & $\begin{array}{l}-.0019 \\
(.0009)\end{array}$ & $\begin{array}{l}-.0019 \\
(.0009)\end{array}$ & $\begin{array}{l}-.0045 \\
(.0011)\end{array}$ & $\begin{array}{l}-.0043 \\
(.0011)\end{array}$ \\
\hline $\begin{array}{l}\text { Unemployment Rate } x \\
\text { Out of Work }<1 \text { year }\end{array}$ & & $\begin{array}{l}-.0022 \\
(.0056)\end{array}$ & & $\begin{array}{l}-.0203 \\
(.0176)\end{array}$ & & $\begin{array}{l}-.0006 \\
(.0029)\end{array}$ & & $\begin{array}{l}-.0097 \\
(.0034)\end{array}$ \\
\hline \multirow[t]{2}{*}{ Out of Work < 1 year } & & $\begin{array}{l}-.0422 \\
(.0096)\end{array}$ & & $\begin{array}{l}.1471 \\
(.0316)\end{array}$ & & $\begin{array}{c}.0032 \\
(.0052)\end{array}$ & & $\begin{array}{l}.0264 \\
(.0072)\end{array}$ \\
\hline & \multicolumn{8}{|c|}{ Females } \\
\hline State Unemployment Rate & $\begin{array}{l}-.0006 \\
(.0020)\end{array}$ & $\begin{array}{l}-.0005 \\
(.0020)\end{array}$ & $\begin{array}{l}-.0214 \\
(.0070)\end{array}$ & $\begin{array}{l}-.0213 \\
(.0070)\end{array}$ & $\begin{array}{l}.0004 \\
(.0005)\end{array}$ & $\begin{array}{c}.0004 \\
(.0005)\end{array}$ & $\begin{array}{l}-.0004 \\
(.0005)\end{array}$ & $\begin{array}{l}-.0004 \\
(.0005)\end{array}$ \\
\hline $\begin{array}{l}\text { Unemployment Rate } x \\
\text { Out of Work }<1 \text { year }\end{array}$ & & $\begin{array}{l}-.0007 \\
(.0051)\end{array}$ & & $\begin{array}{l}-.0048 \\
(.0224)\end{array}$ & & $\begin{array}{c}.0005 \\
(.0012)\end{array}$ & & $\begin{array}{l}-.0022 \\
(.0011)\end{array}$ \\
\hline Out of Work $<1$ year & & $\begin{array}{l}-.0375 \\
(.0083)\end{array}$ & & $\begin{array}{l}.0695 \\
(.0354)\end{array}$ & & $\begin{array}{l}-.0016 \\
(.0020)\end{array}$ & & $\begin{array}{l}.0072 \\
(.0030)\end{array}$ \\
\hline
\end{tabular}

Note: See notes on Tables 2 and 6. The sample is restricted to 25-55 year olds reporting being employed or out of work less than one year at the survey date. The state unemployment rate represents the deviation from the sample mean. The regressions also control for personal characteristics and beer taxes, month and state dummy variables, state-specific linear time trends, and are estimated by WLS using BRFSS final sampling weights. The reference group includes persons working at the survey date. Robust standard errors are shown in parentheses. The sample size for drinking participation is 252,393 for males and 267,322 for females. 
Table A.1: Detailed Regression Results for Selected Specifications

\begin{tabular}{|c|c|c|c|}
\hline Regressor & Drinker & $\begin{array}{c}\text { Log of Number of } \\
\text { Drinks }\end{array}$ & $\begin{array}{c}\text { Alcohol-Involved } \\
\text { Driving }\end{array}$ \\
\hline State Unemployment Rate & $\begin{array}{l}-.0004 \\
(.0008)\end{array}$ & $\begin{array}{l}-.0151 \\
(.0024)\end{array}$ & $\begin{array}{l}-.0004 \\
(.0002)\end{array}$ \\
\hline Beer Tax & $\begin{array}{l}-.0201 \\
(.0033)\end{array}$ & $\begin{array}{l}-.0669 \\
(.0112)\end{array}$ & $\begin{array}{l}-.0042 \\
(.0008)\end{array}$ \\
\hline Age & $\begin{array}{l}.0005 \\
(.0002)\end{array}$ & $\begin{array}{l}-.0033 \\
(.0007)\end{array}$ & $\begin{array}{l}-.0020 \\
(.0001)\end{array}$ \\
\hline Age Squared & $\begin{array}{l}-5.0 \mathrm{E}-5 \\
(1.7 \mathrm{E}-6)\end{array}$ & $\begin{array}{l}-2.8 \mathrm{E}-6 \\
(7.6 \mathrm{E}-6)\end{array}$ & $\begin{array}{c}7.0 \mathrm{E}-6 \\
(4.7 \mathrm{E}-7)\end{array}$ \\
\hline Female & $\begin{array}{l}-.1181 \\
(.0028)\end{array}$ & $\begin{array}{l}-.7994 \\
(.0105)\end{array}$ & $\begin{array}{l}-.0684 \\
(.0012)\end{array}$ \\
\hline \multicolumn{4}{|l|}{ Race/Ethnicity } \\
\hline Black & $\begin{array}{l}-.0997 \\
(.0051)\end{array}$ & $\begin{array}{l}-.3669 \\
(.0244)\end{array}$ & $\begin{array}{l}-.0439 \\
(.0018)\end{array}$ \\
\hline Other Nonwhite & $\begin{array}{l}-.0814 \\
(.0067)\end{array}$ & $\begin{array}{l}-.2239 \\
(.0292)\end{array}$ & $\begin{array}{l}-.0184 \\
(.0026)\end{array}$ \\
\hline Hispanic & $\begin{array}{l}.0050 \\
(.0065)\end{array}$ & $\begin{array}{l}.0424 \\
(.0276)\end{array}$ & $\begin{array}{l}-.0031 \\
(.0026)\end{array}$ \\
\hline Race Not Reported & $\begin{array}{l}-.0344 \\
(.0103)\end{array}$ & $\begin{array}{l}-.0269 \\
(.0414)\end{array}$ & $\begin{array}{l}-.0035 \\
(.0030)\end{array}$ \\
\hline Hispanic Not Reported & $\begin{array}{l}-.0276 \\
(.0090)\end{array}$ & $\begin{array}{l}.0349 \\
(.0411)\end{array}$ & $\begin{array}{l}-.0007 \\
(.0026)\end{array}$ \\
\hline \multicolumn{4}{|l|}{ Education } \\
\hline High School Dropout & $\begin{array}{l}-.0920 \\
(.0015)\end{array}$ & $\begin{array}{l}.0225 \\
(.0076)\end{array}$ & $\begin{array}{l}-.0043 \\
(.0004)\end{array}$ \\
\hline Some College & $\begin{array}{l}.0622 \\
(.0013)\end{array}$ & $\begin{array}{l}-.0214 \\
(.0046)\end{array}$ & $\begin{array}{l}.0010 \\
(.0004)\end{array}$ \\
\hline College Graduate & $\begin{array}{l}.1281 \\
(.0014)\end{array}$ & $\begin{array}{l}-.0572 \\
(.0046)\end{array}$ & $\begin{array}{l}-.0011 \\
(.0004)\end{array}$ \\
\hline Not Reported & $\begin{array}{l}-.0827 \\
(.0092)\end{array}$ & $\begin{array}{l}-.0300 \\
(.0655)\end{array}$ & $\begin{array}{l}-.0056 \\
(.0018)\end{array}$ \\
\hline \multicolumn{4}{|l|}{ Marital Status } \\
\hline Married & $\begin{array}{l}-.0395 \\
(.0016)\end{array}$ & $\begin{array}{l}-.2995 \\
(.0033)\end{array}$ & $\begin{array}{l}-.0252 \\
(.0006)\end{array}$ \\
\hline Divorced/Separated & $\begin{array}{l}.0206 \\
(.0019)\end{array}$ & $\begin{array}{l}-.0401 \\
(.0065)\end{array}$ & $\begin{array}{l}-.0057 \\
(.0007)\end{array}$ \\
\hline Widowed & $\begin{array}{l}-.0391 \\
(.0022)\end{array}$ & $\begin{array}{l}-.2325 \\
(.0104)\end{array}$ & $\begin{array}{l}-.0177 \\
(.0006)\end{array}$ \\
\hline Not Reported & $\begin{array}{l}-.0680 \\
(.0113)\end{array}$ & $\begin{array}{l}-.2299 \\
(.0508)\end{array}$ & $\begin{array}{l}-.0207 \\
(.0028)\end{array}$ \\
\hline \multicolumn{4}{|l|}{ Interactions } \\
\hline Age x Female & $\begin{array}{l}-.0003 \\
(.0001)\end{array}$ & $\begin{array}{l}.0013 \\
(.0002)\end{array}$ & $\begin{array}{c}.0009 \\
(1.9 \mathrm{E}-5)\end{array}$ \\
\hline Age x Black & $\begin{array}{l}.0006 \\
(.0001)\end{array}$ & $\begin{array}{l}.0043 \\
(.0006)\end{array}$ & $\begin{array}{c}.0006 \\
(2.3 \mathrm{E}-5)\end{array}$ \\
\hline Age $x$ Other Race & $\begin{array}{l}2.8 \mathrm{E}-5 \\
(.0001)\end{array}$ & $\begin{array}{l}.0013 \\
(.0007)\end{array}$ & $\begin{array}{c}.0003 \\
(4.0 \mathrm{E}-5)\end{array}$ \\
\hline Age $\mathrm{x}$ Hispanic & $\begin{array}{l}.0002 \\
(.0001)\end{array}$ & $\begin{array}{l}-.0010 \\
(.0007)\end{array}$ & $\begin{array}{l}.0001 \\
(4.0 \mathrm{E}-5)\end{array}$ \\
\hline Female x Black & $\begin{array}{l}-.0432 \\
(.0037)\end{array}$ & $\begin{array}{l}-.0799 \\
(.0146)\end{array}$ & $\begin{array}{c}.0087 \\
(.0011)\end{array}$ \\
\hline Female x Other Race & $\begin{array}{l}-.0514 \\
(.0046)\end{array}$ & $\begin{array}{l}-.0564 \\
(.0189)\end{array}$ & $\begin{array}{l}-.0010 \\
(.0016)\end{array}$ \\
\hline Female $\mathrm{x}$ Hispanic & $\begin{array}{l}-.0666 \\
(.0046)\end{array}$ & $\begin{array}{l}-.1339 \\
(.0173)\end{array}$ & $\begin{array}{l}-.0042 \\
(.0017)\end{array}$ \\
\hline
\end{tabular}


Note: See note on table 2. The econometric models include state and month dummy variables, as well as the regressors displayed, and correspond to those in column (a) of Table 2. 
Table A.2:

Predicted Effect of a Sustained One Percentage Point Increase in the State Unemployment Rate For Population Subgroups

\begin{tabular}{|c|c|c|c|c|c|c|}
\hline \multirow{2}{*}{$\begin{array}{l}\text { Months Since Rise } \\
\text { in Unemployment }\end{array}$} & \multirow[b]{2}{*}{ Males } & \multicolumn{5}{|c|}{ Non-Hispanic } \\
\hline & & Females & Whites & Blacks & Other & Hispanics \\
\hline & \multicolumn{6}{|c|}{ Drinker } \\
\hline $\mathbf{0}$ & $\begin{array}{l}-.0216 \\
(.0056)\end{array}$ & $\begin{array}{l}-.0056 \\
(.0058)\end{array}$ & $\begin{array}{l}-.0116 \\
(.0044)\end{array}$ & $\begin{array}{l}-.0203 \\
(.0104)\end{array}$ & $\begin{array}{l}-.0492 \\
(.0213)\end{array}$ & $\begin{array}{l}-.0208 \\
(.0167)\end{array}$ \\
\hline 3 & $\begin{array}{l}-.0125 \\
(.0006)\end{array}$ & $\begin{array}{l}-.0144 \\
(.0050)\end{array}$ & $\begin{array}{l}-.0111 \\
(.0043)\end{array}$ & $\begin{array}{l}-.0087 \\
(.0113)\end{array}$ & $\begin{array}{l}-.0714 \\
(.0216)\end{array}$ & $\begin{array}{l}-.0200 \\
(.0167)\end{array}$ \\
\hline 9 & $\begin{array}{l}-.0059 \\
(.0042)\end{array}$ & $\begin{array}{l}-.0039 \\
(.0035)\end{array}$ & $\begin{array}{l}-.0022 \\
(.0032)\end{array}$ & $\begin{array}{l}-.0168 \\
(.0086)\end{array}$ & $\begin{array}{l}-.0442 \\
(.0156)\end{array}$ & $\begin{array}{l}-.0075 \\
(.0123)\end{array}$ \\
\hline \multirow[t]{2}{*}{18} & $\begin{array}{l}.0040 \\
(.0021)\end{array}$ & $\begin{array}{l}-.0078 \\
(.0018)\end{array}$ & $\begin{array}{l}.0071 \\
(.0015)\end{array}$ & $\begin{array}{l}-.0013 \\
(.0046)\end{array}$ & $\begin{array}{l}-.0102 \\
(.0064)\end{array}$ & $\begin{array}{l}-.0044 \\
(.0052)\end{array}$ \\
\hline & \multicolumn{6}{|c|}{ Log of Number of Drinks } \\
\hline $\mathbf{0}$ & $\begin{array}{l}-.0497 \\
(.0211)\end{array}$ & $\begin{array}{l}-.0183 \\
(.0194)\end{array}$ & $\begin{array}{l}-.0453 \\
(.0172)\end{array}$ & $\begin{array}{l}.0729 \\
(.0418)\end{array}$ & $\begin{array}{l}.0880 \\
(.0804)\end{array}$ & $\begin{array}{l}-.1200 \\
(.0554)\end{array}$ \\
\hline 3 & $\begin{array}{l}-.0265 \\
(.0212)\end{array}$ & $\begin{array}{l}-.0502 \\
(.0179)\end{array}$ & $\begin{array}{l}-.0412 \\
(.0171)\end{array}$ & $\begin{array}{l}-.0264 \\
(.0436)\end{array}$ & $\begin{array}{l}-.0318 \\
(.0787)\end{array}$ & $\begin{array}{l}.0357 \\
(.0657)\end{array}$ \\
\hline 9 & $\begin{array}{l}-.0618 \\
(.0172)\end{array}$ & $\begin{array}{l}-.0619 \\
(.0140)\end{array}$ & $\begin{array}{l}-.0580 \\
(.0131)\end{array}$ & $\begin{array}{l}.0100 \\
(.0358)\end{array}$ & $\begin{array}{l}-.0761 \\
(.0630)\end{array}$ & $\begin{array}{l}-.1894 \\
(.0540)\end{array}$ \\
\hline \multirow[t]{2}{*}{18} & $\begin{array}{l}-.0151 \\
(.0069)\end{array}$ & $\begin{array}{l}-.0215 \\
(.0064)\end{array}$ & $\begin{array}{l}-.0156 \\
(.0056)\end{array}$ & $\begin{array}{l}-.0134 \\
(.0197)\end{array}$ & $\begin{array}{l}-.0354 \\
(.0296)\end{array}$ & $\begin{array}{l}-.0655 \\
(.0248)\end{array}$ \\
\hline & \multicolumn{6}{|c|}{ Alcohol-Involved Driving } \\
\hline $\mathbf{0}$ & $\begin{array}{l}-.0045 \\
(.0021)\end{array}$ & $\begin{array}{l}.0003 \\
(.0009)\end{array}$ & $\begin{array}{l}-.0012 \\
(.0012)\end{array}$ & $\begin{array}{l}-.0013 \\
(.0024)\end{array}$ & $\begin{array}{l}-.0067 \\
(.0056)\end{array}$ & $\begin{array}{l}-.0109 \\
(.0063)\end{array}$ \\
\hline 3 & $\begin{array}{l}-.0062 \\
(.0022)\end{array}$ & $\begin{array}{l}-.0015 \\
(.0010)\end{array}$ & $\begin{array}{l}-.0027 \\
(.0013)\end{array}$ & $\begin{array}{l}-.0073 \\
(.0031)\end{array}$ & $\begin{array}{l}-.0123 \\
(.0056)\end{array}$ & $\begin{array}{l}-.0036 \\
(.0060)\end{array}$ \\
\hline 9 & $\begin{array}{l}-.0027 \\
(.0017)\end{array}$ & $\begin{array}{l}.0002 \\
(.0007)\end{array}$ & $\begin{array}{l}-.0002 \\
(.0010)\end{array}$ & $\begin{array}{l}-.0008 \\
(.0021)\end{array}$ & $\begin{array}{c}-.0058 \\
(.0050)\end{array}$ & $\begin{array}{l}-.0087 \\
(.0045)\end{array}$ \\
\hline \multirow[t]{2}{*}{18} & $\begin{array}{c}-.0014 \\
(.0008)\end{array}$ & $\begin{array}{c}.0001 \\
(.0003)\end{array}$ & $\begin{array}{c}.0001 \\
(.0005)\end{array}$ & $\begin{array}{l}-.0017 \\
(.0012)\end{array}$ & $\begin{array}{c}-.0014 \\
(.0019)\end{array}$ & $\begin{array}{c}-.0063 \\
(.0019)\end{array}$ \\
\hline & \multicolumn{6}{|c|}{ Heavy Drinking } \\
\hline $\mathbf{0}$ & $\begin{array}{c}-.0059 \\
(.0030)\end{array}$ & $\begin{array}{c}-.0020 \\
(.0015)\end{array}$ & $\begin{array}{c}-.0042 \\
(.0020)\end{array}$ & $\begin{array}{c}.0043 \\
(.0061)\end{array}$ & $\begin{array}{c}.0049 \\
(.0093)\end{array}$ & $\begin{array}{c}-.0144 \\
(.0086)\end{array}$ \\
\hline 3 & $\begin{array}{c}-.0059 \\
(.0034)\end{array}$ & $\begin{array}{l}-.0010 \\
(.0015)\end{array}$ & $\begin{array}{l}-.0037 \\
(.0022)\end{array}$ & $\begin{array}{l}-.0024 \\
(.0054)\end{array}$ & $\begin{array}{c}.0088 \\
(.0081)\end{array}$ & $\begin{array}{l}-.0085 \\
(.0084)\end{array}$ \\
\hline 9 & $\begin{array}{c}-.0082 \\
(.0027)\end{array}$ & $\begin{array}{l}-.0039 \\
(.0012)\end{array}$ & $\begin{array}{l}-.0058 \\
(.0017)\end{array}$ & $\begin{array}{c}-.0041 \\
(.0050)\end{array}$ & $\begin{array}{c}-.0050 \\
(.0077)\end{array}$ & $\begin{array}{l}-.0168 \\
(.0068)\end{array}$ \\
\hline 18 & $\begin{array}{c}-.0012 \\
(.0012)\end{array}$ & $\begin{array}{c}.0005 \\
(.0005)\end{array}$ & $\begin{array}{c}-.0004 \\
(.0007)\end{array}$ & $\begin{array}{c}-.0004 \\
(.0030)\end{array}$ & $\begin{array}{c}.0044 \\
(.0036)\end{array}$ & $\begin{array}{c}-.0044 \\
(.0028)\end{array}$ \\
\hline
\end{tabular}

Note: See notes on Tables 2, 5, and 7. 

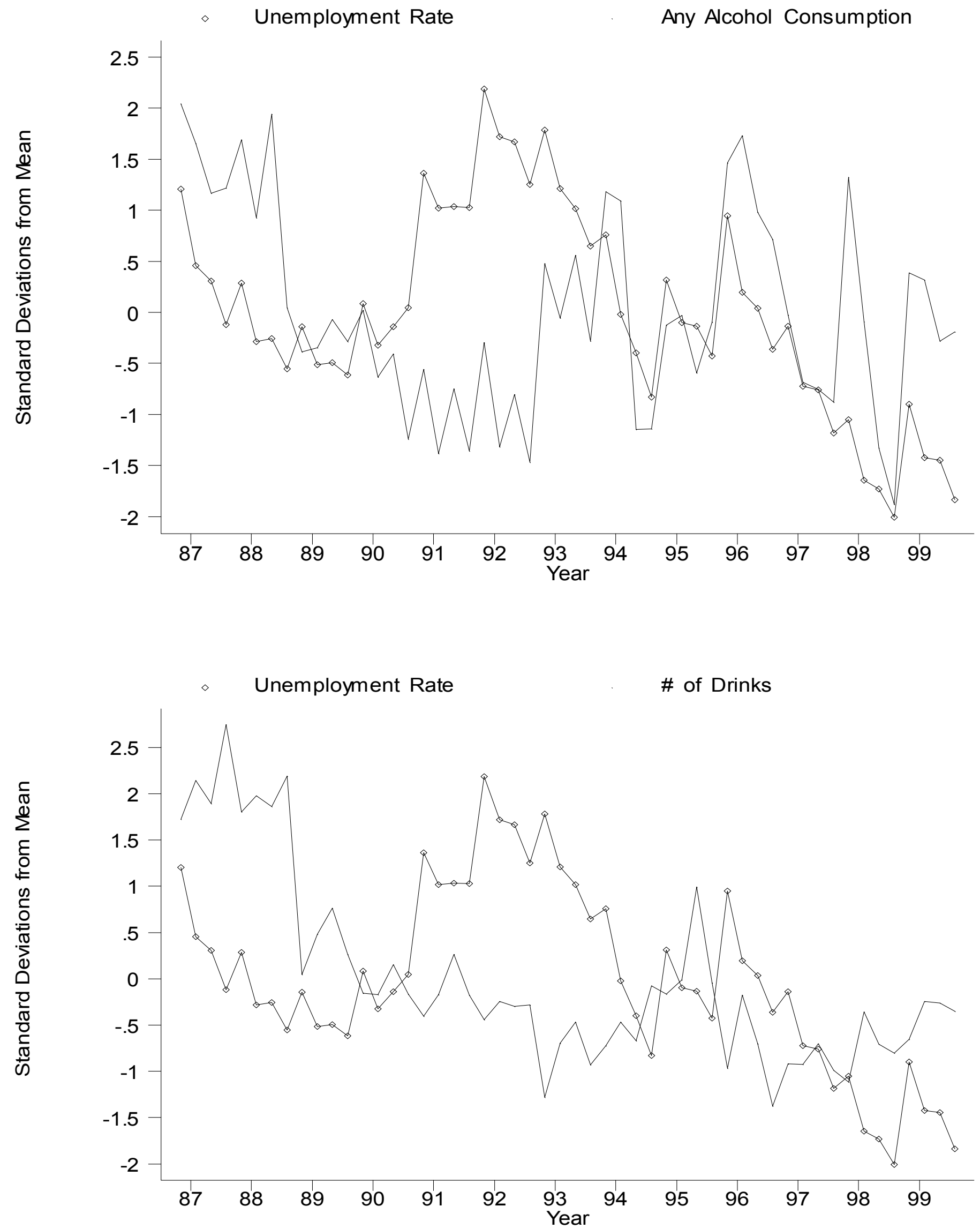

Figure 1: Trends In Unemployment Rates and Alcohol Use 

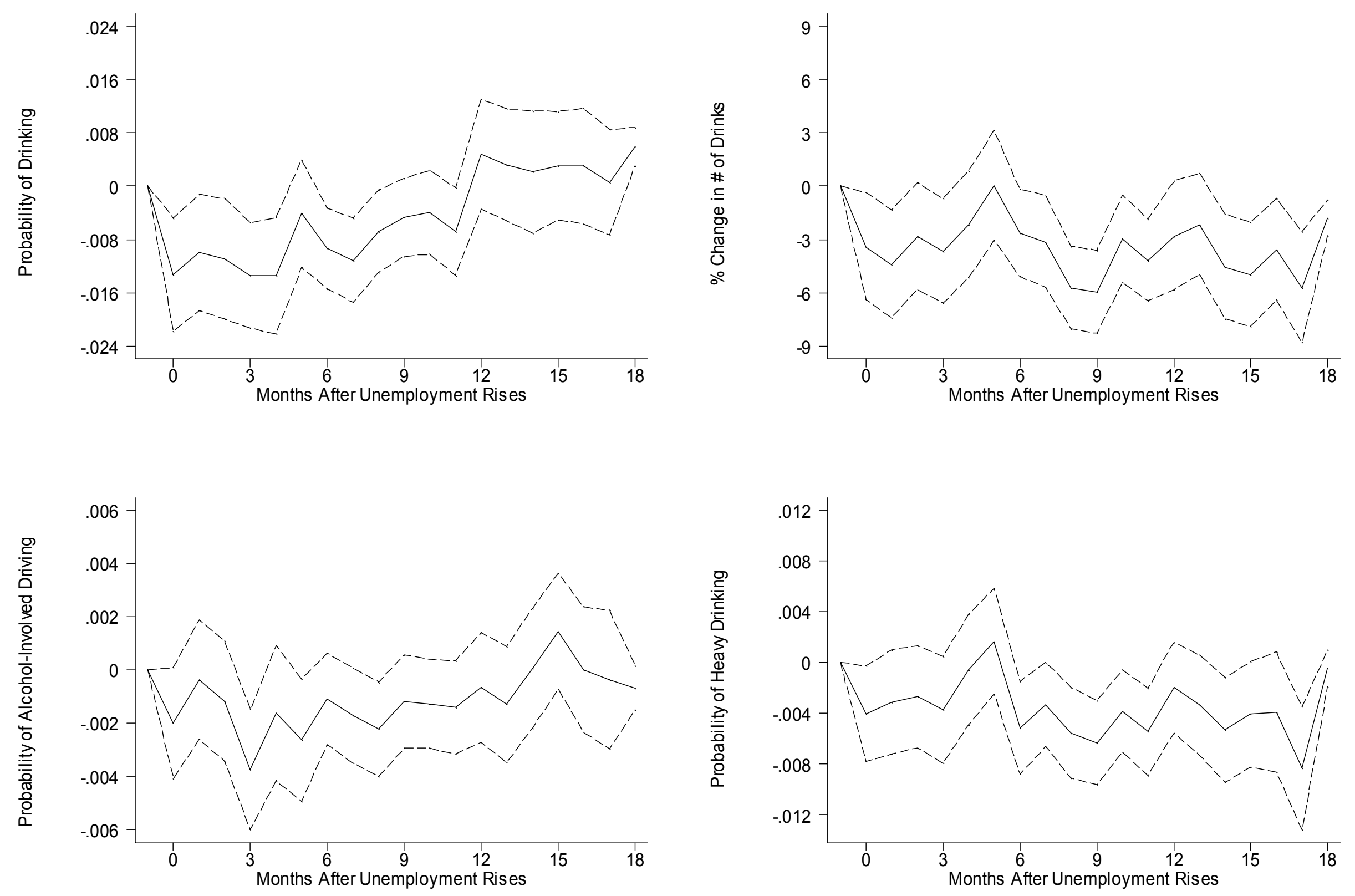

Figure 2: Predicted Effect of a Sustained One Percentage Point Increase in the State Unemployment Rate 